\title{
THE EFFECTS OF HUMAN CAPITAL ATTRIBUTES ON THE EMPLOYABILITY READINESS AMONG ENGINEERING GRADUATES IN THE HIGH EDUCATION INSTITUTE'S IN OMAN
}

\author{
Masoud Rashid Al Hinai \\ PhD Research Fellow \\ Faculty of Business and Accountancy \\ University of Selangor \\ 40000 Shah Alam, Selangor Darul Ehsan, Malaysia \\ E-mail: alhinai6602@gmail.com \\ Dr. Abul Bashar Bhuiyan \\ Associate Professor \\ Faculty of Business and Accountancy \\ University of Selangor \\ 40000 Shah Alam, Selangor Darul Ehsan, Malaysia \\ E-mail: bashariuk@gmail.com \\ Dr. Nor Azilah Husin \\ Associate Professor \& Deputy Dean \\ Faculty of Business and Accountancy \\ University of Selangor \\ 40000 Shah Alam, Selangor Darul Ehsan, Malaysia \\ E-mail: nor_azilah@unisel.edu.my
}

Received: October 01, 2021 Accepted: October 30, 2021 Online Published: November 24, 2021

DOI: $10.46545 /$ aijbms.v3i1.222

URL: https://doi.org/10.46545/aijbms.v3i1.222

\begin{abstract}
The aim of this study is to investigate the effects of human capital attributes on the employability readiness of the engineering graduates of the High Education Institutes in Oman. The study adopted self-directed structured questionnaire distributed to a sample of engineering students and graduates from a number of colleges and universities. The study used the structural equation modelling (SEM) for analysing the collected data. The findings of the statistical analysis of the study showed that Omani graduates signify professional ethics and morality, teamwork including respecting others, cooperating, negotiating, persuading, and contributing to discussions, Communication skills including listening and questioning, Capacity for lifelong learning including openness to new ideas, Creative thinking of the ability to develop and apply appropriate solutions, and Problem solving skills of the ability to analyse facts and situations as the top required skills
\end{abstract}


of Readiness for Employability. Specifically, study findings showed Human capital attributes factor has high influence on the Readiness for Employability of the graduates in Oman. Finally, the study's implementations and recommendations could be transferred to the Gulf and Arab or other countries' contexts having similar settings of HE systems and similar issues of skills gap and employability concern of their graduates.

Keywords: Human Capital Attributes, Employability Readiness, Engineering Graduates, High Education Institutes, Oman.

\section{INTRODUCTION}

The Omani HEIs graduates are considered to have low readiness for employability skills (Lim, Lee, Yap, \& Ling, 2016; Yang, Cheung, \& Fang, 2015). The skills gap of the graduates of the HEIs are affecting the new graduates' employability and career outcomes at workplaces (Al-Azri, 2016). Also, many researches revealed that unemployment rate for Omani nationals under the age of 30 have magnitude values because of the skills Gap of the fresh HEIs graduates (Barnett, Malcolm, \& Toledo, 2015; Belwal, Priyadarshi, \& Al Fazari, 2017; Forstenlechner \& Rutledge, 2010; Silatech \& Bank, 2010). As a result, the principle link between HEIs graduates and the industry lies on the level of graduates' readiness for employability skills that the graduates acquired to match the employer's requirements (Al-Harthi, 2011; Allen \& De Weert, 2007). This link is considered as a principle factor for graduate readiness for employability connecting graduate attributes factors and graduates' attainment of employability skills, attitude, competencies, and knowledge (Clarke, 2018). Also, in an important study of graduates attributes factors affecting the Engineers graduates' attainment of the required Readiness for Employability skills, five attributes factors were believed to have the most influential matters on the acquirement of required employability skills including Human capital attributes, Social capital attributes, Individual attributes, Institution-Related attributes, and Active learning attributes (Al Hinai, Bhuiyan, \& Husin, 2020a, 2020b, 2020c; Rahman \& Bhuiyan, 2019).

Therefore, this study aims to determine the effect of Human Capital attributes factors on the graduates' readiness for employability to improve the quality of engineering education which consequently, will enable the engineering colleges to produce graduates suitable for employment. More specifically, this study aims to answer the following questions.

\section{LITERATURE REVIEW}

\section{Graduate readiness for employability definitions}

The definition of graduate readiness for employability and its concept affect the individuals and their communities in general. Employability or graduate readiness for employability has been the focus of many researches. Some of the newly conducted studies reveal that the concept of employability still has major considerations by researchers, academia, and the industries (Finch, Hamilton, Baldwin, \& Zehner, 2013; Smith, Ferns, \& Russell, 2014; Sumanasiri, Yajid, \& Khatibi, 2015). A new description of graduates' employability which combines the weight of generic soft skills and graduate attributes reveals the usefulness of industrial and work skills attainment (Jackson, 2016). "A set of generic softer skills, in particular, personal attributes that can be summed up as a positive attitude are critical to being employable. A positive attitude encapsulates characteristics such as a willingness to take part and openness to new activities and ideas. It underpins and links together the other key capabilities" (Jackson, 2016). Therefore, the definition 
of Graduate employability or Graduate Readiness for Employability can be understood to indicate the readiness of HEIs graduates to be employed. It signifies the graduates' possession of the required employable skills, knowledge, graduate attributes, attitudes, and workplace tasks requirements to assess them achieving the workplace objectives (Mason, Williams, \& Cranmer, 2009).

\section{Literature review on graduate readiness for employability required skills}

Many types of research were conducted to examine the key soft skills required for the graduates' readiness for employability. For example, in Malaysia, one study revealed students' ethics and their professionalism scored the highest of $19 \%$. While the second soft skills of analytical thinking and problem solving scored $17 \%$. Other important soft skills founded were the abilities of working in a team, leadership and communications. These abilities scored $14 \%$ to $15 \%$. The lowest in importance skills were information management \& lifelong learning and entrepreneurship. These skills got a low score of $10 \%$ each. The study also recommended that it would be effective to recognize the suitable practice and evaluation criteria to guarantee that HEIs students have the required soft skills (Adnan, Daud, Alias, \& Razali, 2017).

Also, in an exploration of global employability skills with the aim to identify the most essential global readiness for employability skills where 43 researches from 17 countries were studied. The findings revealed that they were 10 major skill sets considered as key employability skills. These skill sets were categorised as interpersonal and collaborative skills in which communication skill found to be the most important skills in the category, relationship management skills (team work, flexibility and adaptability), cognitive and problem solving skills (problem solving, analytical/conceptual thinking, and critical thinking), productive selfmanagement skills (organisation, planning, and self-discipline), creative and innovative skills (work independently, entrepreneurship, self-motivated, and innovative thinking), new technology adaptation skills (information computer technology skills and use of modern tools, equipment and technologies), personal attributes and individual differences (ethical conduct, positive attitude, and responsibility), lifelong learning skills, leadership skills, and finally global citizenship skills (Knowledge of another Language and awareness of global issues) (Sarfraz, Rajendran, Hewege, \& Mohan, 2018).

Additionally, a study conducted on the Employability of Undergraduate Students in a Malaysian Higher Educational Institution aiming to explore the employability readiness of Malaysian undergraduates. The study examined few employability attributes including academic, conscientiousness, leadership, critical thinking, teamwork, human and social capital, work and career resilience attributes. it implemented quantitative research approach involving 425 final year undergraduates from Management and Computing and Informatics faculties. The findings of the study illustrated that teamwork, career resilience, and conscientiousness attributes had the highest score. Also, academic, leadership, human, and social capital attributes had lower respondents' rates. Besides, the study revealed that employability among students depends on the academic achievement and study areas. It recommended that curriculum review is essential to consist the required employability attributes (Wong, Samsilah, Siaw, Sulaiman, \& Ab Jalil, 2018). Also, in a study titled as the Critical Analysis on Employment of Graduates in Oman. The study analysed three objectives consisting of the problems confronted by graduates in getting work placement, the problems facing the employers with the outcomes of the current HE system, and the methods to be endorsed to improve the graduates of the HE system to increase job attainment for Omanis. The findings of the study revealed that graduates lacked the technical abilities including design, testing, 
and configuration management, personal skills such as communication and teamwork, and professional qualities. Also, the study illustrated that problems facing the students getting work placement were due to their English language proficiency, communication skills, weakness of understanding basic concepts, and the skills gap between education and employability requirements. The study recommended improving the alignment between the academic curricula and the essential required employability skills, enriching the students' projects to be essential parts of the learning mechanism, and enhancing the virtual training (Edwin \& Sabura, 2019).

There is a recent study titled as "employability under the fourth industrial revolution (UAE)". The study stressed that future labour will depend highly on students' employability skills which are considered as the key factors for sustaining employment. The aim of the study was to determine the employability skills as seen by the HE students' side compared with the labour market employers' requests. A quantitative study utilising a simple random sampling consisting of 216 participants was conducted with questionnaires via the online platform. The findings of the study showed that students lack the understanding of the sets of the employability skills of the fourth industrial revolution indicating a gap of employability skills provided by the HEIs and the labour market demands. The study recommended that the HE subject matter experts to review the programmes of the HEIs and enhance the programmes' learning outcomes to deliver the required future employability skills such as communication, IT skills, foreign languages, and team-work to prepare the students to compete in the future job market (Pauceanu, Rabie, \& Moustafa, 2020).

Moreover. In an interesting study connected to the employability of graduates in Asia. The sets of employability skills required for graduates to be entitled to enter the labour market were analysed. This study was based on studies conducted on graduate employability from Indonesia, Malaysia and the Philippines. The findings of the study revealed that employability depends on a number of attributes and competencies that helps the graduates to get and sustain employment such as: individual attributes (basic social skills, competencies (motivation, confidence), transferable skills (literacy, numeracy, problem-solving, communication, adaptability, team working skills), qualifications, and educational attainment. Besides, individual's social and household circumstances (family and caring responsibilities, access to resources). Additionally, on external factors related to the labour demand situations. The study recommended that students must be equipped with certain employability skills such as motivation, creative thinking, problem solving, communication skills, and the ability to work independently or as part of a team. The study is also found that it is important for graduates to gain the adaptability skills to continuously allow them to update their skill, and learn new technologies. As a result, the study recommended the students to be responsible to continuously enhance the attainment of the required knowledge and skills to meet the demands of the workplace (Tran, 2019).

Also, a research paper on graduate attributes and employability skills investigated the foremost prevalent graduate attributes as they apply to graduates' employability in Oman. The aims of the paper were to survey the key graduate attributes or employability aptitudes from the point of view of business in Oman in specific and the GCC nations in general, to know and acknowledge students' recognitions of the foremost common abilities that managers in Oman give esteem for admitting the entry level employments, and to analyze and contextualize graduate qualities and employability aptitudes from all-encompassing point of view, including Higher Educational Institutions (HEIs), employers, and the students. The research conducted by surveys and interviews with Omani graduates using the principles of 'hypothetic-deductive logic' and inferential analysis using a combination of focus group and survey approach. The findings of the research paper indicated that the domain of higher educational institutes in Oman is basically 
confined to the essential nonspecific abilities in creating the graduate properties. Students' viewpoints on employers' determination criteria uncover that computing abilities, the capacity to work in groups, proficiency of English language, earlier training, and the graduate's identity are the five most critical employability skills in Oman. The study also concluded that at present, there are few interactions among higher educational institutions (HEIs), alumni, and industry in Oman for enhancing the employability of students. It recommended that All the partners in Oman to be compelled to come together to characterize employability skills judiciously by extending the domain beyond generic skills and abilities (Belwal et al., 2017).

Finally, a study on English language proficiency and communicative competence in Oman. The study intended to evaluate their implications for employability and sustainable development. This study raised a major concern about the tremendous collections of human and financial assets the government commit into supporting English language instruction. Nevertheless, this venture has clearly failed to convey the anticipated outcomes with both secondary- and tertiary-level graduates regularly characterized as being weak in the English and as having communication abilities that are insufficient for the workforce. This paper considered number of issues related to the ways in which English language proficiency and communicative competence were created in Omani schools and colleges, with a focus on the challenges that exist inside the government education system. The suggestions of these challenges for graduate employability and feasible advancement were investigated. The study recommended methods of aligning the gap between students' English language abilities and the requests of the industry in Oman (Al-Mahrooqi \& Denman, 2018).

\section{Literature Review in Human Capital attributes affecting Graduates Readiness for Employability}

Human capital Attributes, acknowledged as essential elements for graduates' readiness for employability. A number of researchers have argued the magnitude to which generic skills, soft and technical, considered to be interchangeable from HEIs to the industries, or among employers (Hinchliffe \& Jolly, 2011; Kalfa \& Taksa, 2015). However, skill learning is an essential part of higher education. General required competencies, including problem-solving, critical thinking or team skills, represent a higher order thinking type of skills that are expected to be acquired by $\mathrm{HE}$ graduates. They are considered to be the essential part of graduates' identity. Those skills are linked strongly with career expertise especially for entering highly sophisticated professions such as engineering or medicine. Therefore, Human capital attributes are essential part of graduate employability (Clarke, 2018; Heijde \& Van Der Heijden, 2006).

Since the last two decades of the $20^{\text {th }}$, governments and employer's groups have put high pressure at HEIs to provide evidence of the effectiveness of their higher educational programmes in providing ready to work graduates. From academic perspective, there is a concern about the effectiveness of HEIs used strategies in developing transferable employability skills into their students. Holmes (2013) analysed the ways universities deliver graduate employability required skills and their methods of embedded them into their programme curricula. He also analysed three influencing factors which affects graduate employability. Those factors are the human capital factors, the social capital factors and the individual behaviour factors. He proposed an employability frame work consisting of the above factors as main independent variables and contains for the human capitals; skills, competencies and work experience, for social capital; network, social class and university ranking and for the individual behaviour; career selfmanagement and career building skills (Holmes, 2013). 
Finally, a new approach to employability was considered by developing a framework that incorporates six key dimensions which included human capital, social capital, individual attributes, individual behaviours, perceived employability, and labour market factors. The study was based on UK and Australian data. The study model contributed to our understanding of the individual, institutional and contextual variables that impact employability and career results among graduates. Moreover, the model also identified zones of individual obligation (for students and graduates) and zones for potential collaboration between colleges, work providers and industry sections. At last, this model advertised a multidisciplinary point of view in this manner laying the establishment for future investigations and collaborations between higher education specialists, career analysts and researchers from related areas, such as administration and psychology. The paper suggested to be expanded to incorporate labour market factor (Clarke, 2018).

The initial theoretical framework representing the relationship among the study variables is presented in figure 1 below. This portion of the framework is obtained from a wider study of factors affecting the Readiness for employability among Engineering graduates of the HEIs in Oman (Al Hinai et al., 2020b).

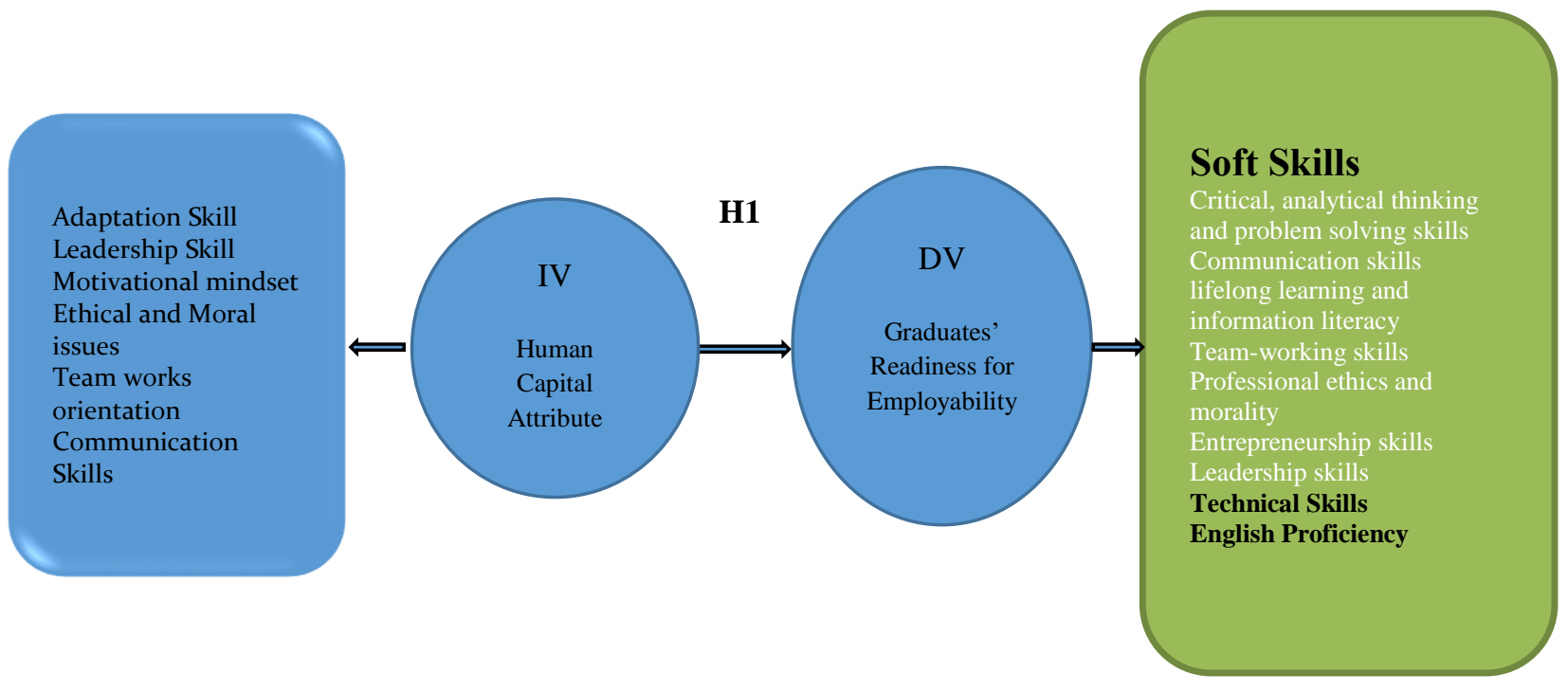

Figure 1. The influence of Human Capital Attributes on Graduates' Readiness for Employability among Engineering graduates of the HEIs in Oman

\section{$H_{1}:$ There is a significant relationship between human capital attributes and graduate's readiness for employability among Engineering graduates of the HEIs in Oman.}

\section{METHODOLOGY}

The simple random characteristic strategy of the sampling technique was utilised by collecting data from an intended sample consisting from 340 random sample of engineering students obtained from different HEIs in Oman. To ensure the validity and clarity of the questionnaires, a panel of experts were consulted consisting of two academic engineering experts and two language experts. The findings of this study are accomplished utilizing the quantitative statistical methodology approach. This approach implements a numerical analysis using survey questionnaires as the base to collect data from students, and graduates (Creswell \& Creswell, 2017; Dörnyei, 2007). Also, Human Capital Theory were utilised as the underpinning theory of the study since it examines the financial benefits resulting from the investments in people' skills and resources. Such investment 
will result to have highly-skilled labors placed in highly-skilled careers, which could improve the nation's economy and prosperity (Becker, 1962; Leslie \& Brinkman, 1988; McMahon, 2009; Schultz, 1963; Slaughter, Taylor, \& Rosinger, 2015).

Two statistical programs are used for data analysis. The first one is the use of the Statistical Package for the Social Studies (SPSS) version 26.0 to administer the preliminary data analysis. The second statistical program utilised for this study was the Partial Least Square Structural Equation Modelling (PLS-SEM) software. This program is used for the evaluation of the reflective measurement model, structural model, path analysis, and hypotheses testing (Hair Jr, Sarstedt, Ringle, \& Gudergan, 2017).

\section{DISCUSSION OF RESEARCH QUESTIONS AND FINDINGS}

By conducting a meta-analysis of the literature review on the Readiness for Employability as part of the human capital attributes, thirteen skills were identified and analysed to determine their levels of importance among the Engineering graduates of the HEIs in Oman. The identified Readiness for Employability skills are listed as:

- Analytical thinking or critical thinking

- Problem solving skills (The ability to analyze facts and situations)

- Creative thinking (The ability to develop and apply appropriate solutions)

- Communication skills including listening and questioning

- Capacity for lifelong learning including readiness to contribute to new ideas

- Capacity for lifelong learning including openness to new ideas

- Teamwork including respecting others, cooperating, negotiating / persuading, and contributing to discussions

- Professional ethics and morality

- Entrepreneurial skills

- Leadership skills

- Proficiency in written and oral English

- Specialization and industrial required technical skills

- Capacity for applying knowledge in practice

Using SPSS version 26, the results obtained from the Engineering student's survey of the study, as indicated by Table 1, has illustrated the following level of importance of the graduates' Readiness for Employability

Table 1. Level of importance of the Readiness for Employability

\begin{tabular}{|c|c|c|c|c|}
\hline Readiness for Employability & Mean & $\begin{array}{c}\text { Level of } \\
\text { Importance }\end{array}$ & $\begin{array}{l}\text { Proportion } \\
\text { of High }\end{array}$ & $\begin{array}{l}\text { Proportion } \\
\text { of Low }\end{array}$ \\
\hline Professional ethics and morality & 6.3059 & 1 & $95 \%$ & $2.6 \%$ \\
\hline $\begin{array}{l}\text { Teamwork including respecting others, } \\
\text { cooperating, negotiating / persuading, and } \\
\text { contributing to discussions }\end{array}$ & 6.2765 & 2 & $94 \%$ & $3 \%$ \\
\hline $\begin{array}{l}\text { Communication skills including listening and } \\
\text { questioning }\end{array}$ & 6.0206 & 3 & $92 \%$ & $3.8 \%$ \\
\hline
\end{tabular}




\begin{tabular}{|c|c|c|c|c|}
\hline $\begin{array}{l}\text { Capacity for lifelong learning including } \\
\text { openness to new ideas }\end{array}$ & 5.8441 & 4 & $89 \%$ & $3 \%$ \\
\hline $\begin{array}{l}\text { Creative thinking (The ability to develop and } \\
\text { apply appropriate solutions) }\end{array}$ & 5.8265 & 5 & $86 \%$ & $4 \%$ \\
\hline $\begin{array}{l}\text { Problem solving skills (The ability to analyse } \\
\text { facts and situations) }\end{array}$ & 5.8118 & 6 & $88 \%$ & $5 \%$ \\
\hline $\begin{array}{l}\text { Capacity for lifelong learning including } \\
\text { readiness to contribute to new ideas }\end{array}$ & 5.6618 & 7 & $85.6 \%$ & $4.4 \%$ \\
\hline Capacity for applying knowledge in practice & 5.6324 & 8 & $87 \%$ & $6 \%$ \\
\hline Leadership skills & 5.5794 & 9 & $82 \%$ & $6.8 \%$ \\
\hline Proficiency in written and oral English & 5.5353 & 10 & $92 \%$ & $4.7 \%$ \\
\hline $\begin{array}{l}\text { Specialization and industrial required technical } \\
\text { skills }\end{array}$ & 5.3941 & 11 & $79 \%$ & $8.5 \%$ \\
\hline Analytical thinking or critical thinking & 5.3000 & 12 & $73 \%$ & $7 \%$ \\
\hline Entrepreneurial skills & 4.9824 & 13 & $64 \%$ & $13 \%$ \\
\hline
\end{tabular}

The results of the study clearly illustrate the importance of Professional ethics and morality, Teamwork including respecting others, cooperating, negotiating / persuading, and contributing to discussions, Communication skills including listening and questioning, Capacity for lifelong learning including openness to new ideas, Creative thinking (The ability to develop and apply appropriate solutions), and Problem-solving skills (The ability to analyze facts and situations). These six Readiness for Employability skills are considered by the Omani Engineering graduates as the most important skills. Such findings support the findings of Adnan et al., (2017) where he found that ethics \& professionalism had ranked the highest in importance followed by teamwork, and communications were also among the highest important skills required for employability. Also, the study findings support the importance of teamwork skills among Omani graduates that found by Belwal et al., (2017) where he found that computing skills, teamwork, proficiency of English language, placement training, and the personality of the graduates were the five most required employability skills in Oman. Besides, the study finding are even supported when communication, teamwork, and professional qualities were found as the most essential skills required for Omani graduates (Edwin \& Sabura, 2019). While critical thinking and problem solving skills had been also found as important Readiness for Employability skills (Mtawa, Fongwa, \& Wilson-Strydom, 2019).

Though the findings, illustrated in Table 1 shows that the Proficiency in written and oral English is ranking at level 10 of importance, yet its proportion of high is $92 \%$ and knowing that the mean of communication of Engineering in Oman is English, therefore, it can be considered to have a high level of importance and can be justified with the Communication skills. The English communication skill among engineering students consisting of both written and oral communication is one of the key barriers that face graduates to engage effectively in the interviews (Al-Mahrooqi \& Denman, 2016). This view is consistent with other studies, who mentioned that developing learners' communicative capability is one of the challenges of Oman's HE system as it falls short to produce fluent English proficient graduates. As a result, the critical value of English 
proficiency is recognised as an essential skill to gaining knowledge and pursuing employment's opportunities (Al-Mahrooqi \& Denman, 2016).

Table 2. Summary of measurement model findings

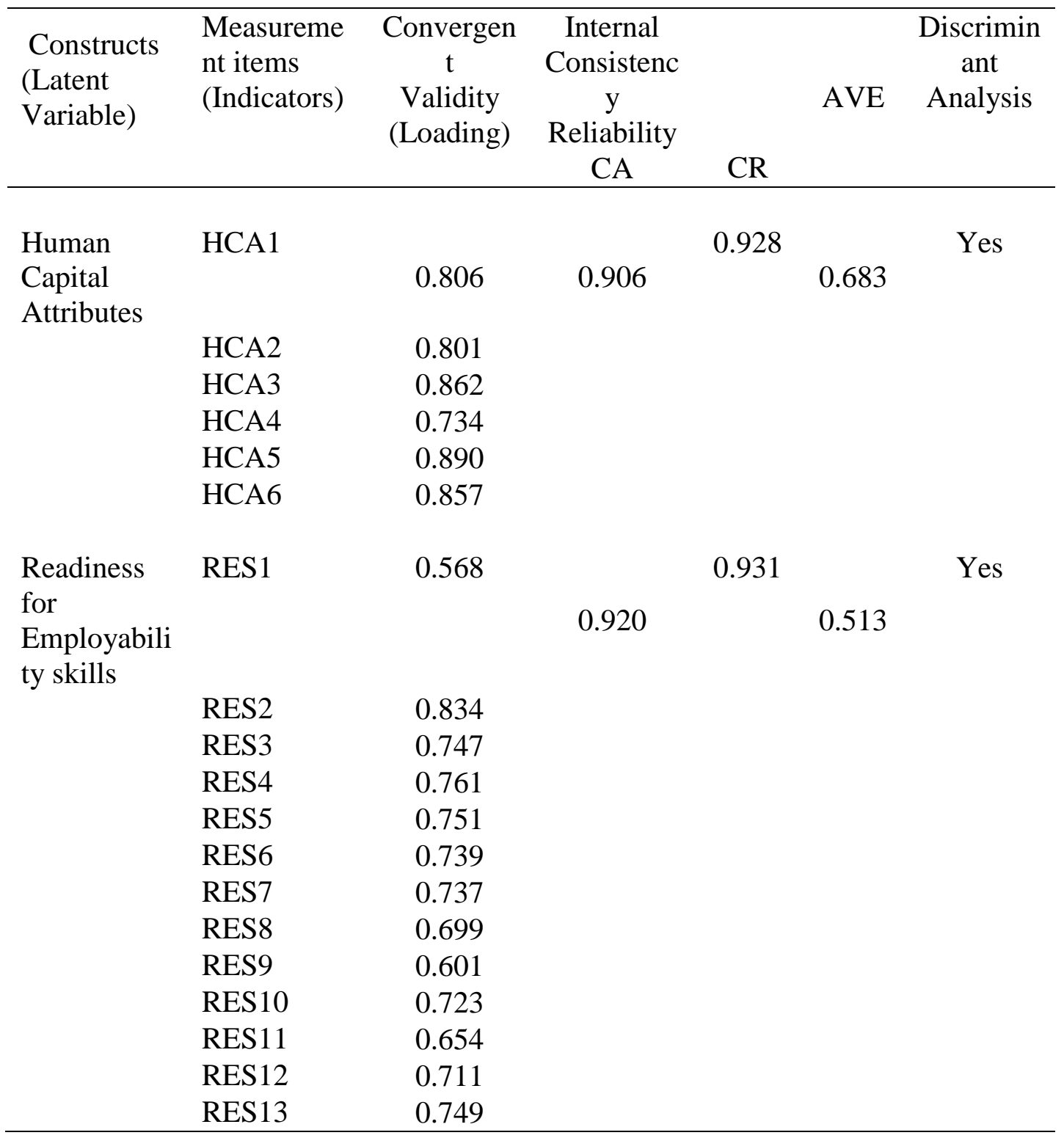

Table 2 highlights a brief summary of the results obtained for the measurement model assessment.

The measurement model assessment illustrates that all the requirements of reliability and validity of the measurement model assessment are met.

\section{Hypotheses Testing}

To conduct the hypotheses testing connected to the structural model of the study, PLS-SEM Version 3.0 is used (Hair Jr et al., 2017). There are several elements are required to be considered. The first element, for a hypothesis to be valid, the value of the path coefficient of 0.1 or higher is 
required to account for a certain impact within the model (Hair, Ringle, \& Sarstedt, 2011). Secondly, the acceptable t-value and p-value must be greater than 1.96 and less than 0.05 respectively (Ramayah, Cheah, Chuah, Ting, \& Memon, 2018). The hypothesis testing result of the impact of Human Capital Attributes on the Readiness for Employability is illustrated on table 3 .

Table 3. The hypothesis testing result of the impact of Human Capital Attributes on the Readiness for Employability

\begin{tabular}{lcccccc}
\hline Hypothesis H1 & $\begin{array}{c}\text { Path } \\
\text { Coefficient } \\
\beta\end{array}$ & $\begin{array}{c}\text { T } \\
\text { Statistics }\end{array}$ & $\begin{array}{c}\text { P } \\
\text { Values }\end{array}$ & $\begin{array}{c}5 \% \\
\text { BCI } \\
\text { LL }\end{array}$ & $\begin{array}{c}95 \% \\
\text { BCI } \\
\text { UL }\end{array}$ & $\begin{array}{c}\text { Decision } \\
(\mathrm{p}< \\
0.05)\end{array}$ \\
\hline $\begin{array}{l}\text { Human Capital Attributes - } \\
\begin{array}{l}\text { Readiness for } \\
\text { Employability }\end{array}\end{array}$ & 0.472 & 6.159 & 0.000 & 0.338 & 0.585 & Accepted \\
\hline
\end{tabular}

The findings of the study showed significant relationship between the Readiness for Employability and Human Capital attributes (H1). This finding illustrates that, there is a big influence of the Human Capital attributes on the Readiness for Employability of the Engineering graduates of the HEIs in Oman. This finding enhances the study conducted by Holmes (2013), when he determined that Human Capital attributes played a major role in delivering the graduate employability required skills when HEIs utilised suitable methods of embedded the required Knowledge, Skills, and Attitudes of the graduates into their programme curricula. Also, the study findings support the finding of Clark (2018), who stressed that most work providers, HEIs, and governments had concentrated on graduate Readiness for Employability from a human capital perspective. The underlying belief is that the acquirement of some specific skills and abilities that are considered as human capital attributes such as problem-solving, critical thinking, team work, and adaptability or openness to new challenges will result in enhanced graduate Readiness for employability (Clarke, 2018; Kalfa \& Taksa, 2015).

\section{CONCLUSION AND POLICY RECOMMENDATION}

The current study remarked the determination of the set of the graduates' Readiness for employability skills and their level of importance as seen from HEIs/ students and graduates. Since students and graduates believe that HEIs/Engineering departments are responsible for preparing them for a highly competitive labor market through improving their skills attainment, academic achievement, and professional abilities, therefore, the finding of this study should be used as guide lines for Ministry of Higher Education, HEIs' Engineering departments, course designers, and policy makers to improve the quality of the students and eliminate the skills gap of the graduates thus enhancing graduates employability and achievement throughout their career life cycle.

One important recommendation is for the Ministry of Higher Education, HEIs' Engineering departments, course designers, and policy makers to utilize the set of studied graduates' Readiness for Employability skills to develop adequate engineering programmes having suitable employability-related curriculum and outcomes in accordance with the needs and requirement of the labor market. More skills-oriented activities and practices should be embedded in the core curriculum and delivered to students in the classrooms, workshops, and industrial visits. 
Such practice will contribute effectively to the engagement with the desired learning goals, and skills requirement so achieving practical outcome and improving students Readiness for Employability. Besides, the requirements of the Readiness for Employability skills must be updated regularly. One suggestion is to create a sub department in each HEI to work as a link between the HEIs and the most popular industrial organizations so as, detecting new skills required as well as new techniques and or new technologies introduced, and advised the HEIs to update their curricula, syllabi, specializations and programmes offered to improve quality and employability of the graduates.

In conclusion, this paper has analyzed the objective of measuring the levels of importance of the Readiness for Employability skills among the engineering graduates of the HEIs in Oman. By conducting a meta-analysis process of literature reviews of the recent published papers, thirteen skills were identified and analysed to determine their levels of importance among the Engineering graduates of the HEIs in Oman. The identified Readiness for Employability skills are listed as: Analytical thinking or critical thinking, Problem solving skills (The ability to analyze facts and situations), Creative thinking (The ability to develop and apply appropriate solutions), Communication skills including listening and questioning, Capacity for lifelong learning including readiness to contribute to new ideas, Capacity for lifelong learning including openness to new ideas, Teamwork including respecting others, cooperating, negotiating / persuading, and contributing to discussions, Professional ethics and morality, Entrepreneurial skills, Leadership skills, Proficiency in written and oral English, Specialization and industrial required technical skills, and Capacity for applying knowledge in practice. The results of the study clearly illustrate the importance of Professional ethics and morality, Teamwork including respecting others, cooperating, negotiating / persuading, and contributing to discussions, Communication skills including listening and questioning, Capacity for lifelong learning including openness to new ideas, Creative thinking (The ability to develop and apply appropriate solutions), and Problem solving skills (The ability to analyze facts and situations) as the six most important Readiness for Employability skills considered by the Omani engineering graduates. Therefore, the finding of this study should be used as guide lines for Ministry of Higher Education, HEIs' Engineering departments, course designers, and policy makers to improve the quality of the students and eliminate the skills gap of the graduates thus enhancing graduates employability and achievement throughout their career life cycle by developing adequate engineering programmes having suitable employability-related curriculum and outcomes in accordance with the needs and requirement of the labor market. More skills-oriented activities and practices should be embedded in the core curriculum and delivered to students in the classrooms, workshops, and industrial visits. Such practice will contribute effectively to the engagement with the desired learning goals, and skills requirement so achieving practical outcome and improving students Readiness for Employability.

\section{REFERENCES}

Adnan, Y. M., Daud, M. N., Alias, A., \& Razali, M. N. (2017). Importance of soft skills for graduates in the real estate programmes in Malaysia. Journal of Surveying, Construction and Property, 3(2).

Al-Azri, A. K. H. (2016). Academics', students', employers', and graduates' perceptions towards business management and administration undergraduate employability: implications for higher education and industry in Oman. Brunel University London, 
Al-Harthi, H. K. (2011). University student perceptions of the relationship between university education and the labour market in Egypt and Oman. Prospects, 41(4), 535-551.

Al-Mahrooqi, R., \& Denman, C. (2018). English language proficiency and communicative competence in Oman: Implications for employability and sustainable development. In English Education in Oman (pp. 181-193): Springer.

Al-Mahrooqi, R., \& Denman, C. J. (2016). Omani graduates' English-language communication skills in the workforce: Employees' perspectives. International Journal of Applied Linguistics and English Literature, 5(4), 172-182.

Al Hinai, M. R., Bhuiyan, A. B., \& Husin, N. A. (2020a). AN EMPIRICAL REVIEW ON THE GRADUATE ATTRIBUTES AND READINESS FOR EMPLOYABILITY AMONG THE ENGINEERING GRADUATES IN THE HIGHER EDUCATION INSTITUTIONS (HEIs). Indian Journal of Finance and Banking, 4(3), 8-25.

Al Hinai, M. R., Bhuiyan, A. B., \& Husin, N. A. (2020b). THE MODERATING EFFECTS OF GENDER, CAREER, MORAL MINDSET ON THE RELATIONSHIP BETWEEN THE GRADUATE ATTRIBUTES AND READINESS FOR EMPLOYABILITY AMONG ENGINEERING COLLEGES GRADUATES IN OMAN. International Journal of Accounting \& Finance Review, 5(3), 16-30.

Al Hinai, M. R., Bhuiyan, A. B., \& Husin, N. A. (2020c). Theoretical Review on The Graduate Attributes and The Readiness for Employability Among Engineering Graduates in The Higher Education Institutes (HEIs) in Oman. Indian Journal of Finance and Banking, 4(2), 130-139.

Allen, J., \& De Weert, E. (2007). What do educational mismatches tell us about skill mismatches? A cross-country analysis. European Journal of Education, 42(1), 59-73.

Barnett, A. H., Malcolm, M., \& Toledo, H. (2015). Shooting the goose that lays the golden egg: the case of UAE employment policy. Journal of Economic Studies, 42(2), 285-302.

Becker, G. S. (1962). Investment in human capital: A theoretical analysis. Journal of political economy, 70(5, Part 2), 9-49.

Belwal, R., Priyadarshi, P., \& Al Fazari, M. H. (2017). Graduate attributes and employability skills: Graduates' perspectives on employers' expectations in Oman. International Journal of Educational Management, 31(6), 814-827.

Clarke, M. (2018). Rethinking graduate employability: The role of capital, individual attributes and context. Studies in Higher Education, 43(11), 1923-1937.

Creswell, J. W., \& Creswell, J. D. (2017). Research design: Qualitative, quantitative, and mixed methods approaches: Sage publications. 
Dörnyei, Z. (2007). Research methods in applied linguistics: Quantitative, qualitative, and mixed methodologies: Oxford University Press Oxford.

Edwin, M. M. D., \& Sabura, F. M. (2019). Critical Analysis on Employment of Graduates in Oman.

Finch, D. J., Hamilton, L. K., Baldwin, R., \& Zehner, M. (2013). An exploratory study of factors affecting undergraduate employability. Education+ Training, 55(7), 681-704.

Forstenlechner, I., \& Rutledge, E. (2010). Unemployment in the Gulf: time to update the "social contract”. Middle East Policy, 17(2), 38-51.

Hair, J. F., Ringle, C. M., \& Sarstedt, M. (2011). PLS-SEM: Indeed a silver bullet. Journal of Marketing theory and Practice, 19(2), 139-152.

Hair Jr, J. F., Sarstedt, M., Ringle, C. M., \& Gudergan, S. P. (2017). Advanced issues in partial least squares structural equation modeling: saGe publications.

Heijde, C. M. V. D., \& Van Der Heijden, B. I. (2006). A competence-based and multidimensional operationalization and measurement of employability. Human Resource Management: Published in Cooperation with the School of Business Administration, The University of Michigan and in alliance with the Society of Human Resources Management, 45(3), 449476.

Hinchliffe, G. W., \& Jolly, A. (2011). Graduate identity and employability. British Educational Research Journal, 37(4), 563-584.

Holmes, L. (2013). Competing perspectives on graduate employability: possession, position or process? Studies in Higher Education, 38(4), 538-554.

Jackson, D. (2016). Skill mastery and the formation of graduate identity in Bachelor graduates: evidence from Australia. Studies in Higher Education, 41(7), 1313-1332.

Kalfa, S., \& Taksa, L. (2015). Cultural capital in business higher education: reconsidering the graduate attributes movement and the focus on employability. Studies in Higher Education, 40(4), 580-595.

Leslie, L. L., \& Brinkman, P. T. (1988). The Economic Value of Higher Education. American Council on Education/Macmillan Series on Higher Education: ERIC.

Lim, Y.-M., Lee, T. H., Yap, C. S., \& Ling, C. C. (2016). Employability skills, personal qualities, and early employment problems of entry-level auditors: Perspectives from employers, lecturers, auditors, and students. Journal of Education for Business, 91(4), 185-192. 
Mason, G., Williams, G., \& Cranmer, S. (2009). Employability skills initiatives in higher education: what effects do they have on graduate labour market outcomes? Education Economics, 17(1), 1-30.

McMahon, W. W. (2009). Higher learning, greater good: The private and social benefits of higher education: JHU Press.

Mtawa, N., Fongwa, S., \& Wilson-Strydom, M. (2019). Enhancing graduate employability attributes and capabilities formation: a service-learning approach. Teaching in Higher Education, 1-17.

Pauceanu, A. M., Rabie, N., \& Moustafa, A. (2020). Employability under the Fourth Industrial Revolution. Economics \& Sociology, 13(3), 269-283.

Rahman, M. Z., \& Bhuiyan, A. B. (2019). The Influencing Factors on the Effectiveness of Foundation Training Programs: A Case Study of the Health Cadre Service in Bangladesh. International Journal of Business and Management Future, 3(2), 13-21.

Ramayah, T., Cheah, J., Chuah, F., Ting, H., \& Memon, M. (2018). Partial least squares structural equation modeling (PLS-SEM) using smartPLS 3.0. In An Updated Guide and Practical Guide to Statistical Analysis: Pearson.

Sarfraz, I., Rajendran, D., Hewege, C., \& Mohan, M. D. (2018). An exploration of global employability skills: a systematic research review. International Journal of Work Organisation and Emotion, 9(1), 63-88.

Schultz, T. (1963). The Economics Value of Education . New York and London. Columbia. In: University Press.

Silatech, G., \& Bank, W. (2010). The Silatech Index: Voices of Young Arabs. In: Gallup Center for Muslim Studies, Silatech Washington, DC.

Slaughter, S., Taylor, B. J., \& Rosinger, K. O. (2015). A critical reframing of human capital theory in US higher education. Critical approaches to the study of higher education: A practical introduction, 80-102.

Smith, C., Ferns, S., \& Russell, L. (2014). Conceptualising and measuring'employablity'-lessons from a National OLT Project. Paper presented at the http://acen. edu. au/2014-conferenceproceedings/.

Sumanasiri, E. G. T., Yajid, M. S. A., \& Khatibi, A. (2015). Conceptualizing Learning and Employability" Learning and Employability Framework". Journal of Education and Learning, 4(2), 53-63.

Tran, T. T. (2019). GRADUATE EMPLOYABILITY. Innovate higher education to enhance graduate employability: Rethinking the possibilities, 158. 
Wong, S. P., Samsilah, R., Siaw, Y.-L., Sulaiman, T., \& Ab Jalil, H. (2018). The Employability of Undergraduate Students in a Malaysian Higher Educational Institution. Educational Leader (Pemimpin Pendidikan), 6, 165-182.

Yang, H., Cheung, C., \& Fang, C. C. (2015). An empirical study of hospitality employability skills: perceptions of entry-level hotel staff in China. Journal of Hospitality \& Tourism Education, 27(4), 161-170.

\section{Copyrights}

Copyright for this article is retained by the author(s), with first publication rights granted to the journal. This is an open-access article distributed under the terms and conditions of the Creative Commons Attribution license (https://creativecommons.org/licenses/by/4.0). 